\title{
Waste Silica as a Valuable Component of Extensive Green-Roof Substrates
}

\author{
Anna Krawczyk*, Iwona Domagała-Świątkiewicz, \\ Agnieszka Lis-Krzyścin, Małgorzata Daraż \\ Unit of Plant Nutrition, Institute of Plant Biology and Biotechnology, Faculty of Biotechnology and Horticulture, \\ University of Agriculture, 29 Listopada 54, 31-425 Krakow, Poland
}

Received: 3 March 2016

Accepted: 22 August 2016

\begin{abstract}
Green roofs are becoming increasingly common practice of the urban sustainable environment. The growing substrate is the most important part of green-roof technology. The cost of engineering substrates can be reduced by using locally available components. Since green roofs are a relatively new concept in Poland, there is a need to examine substrate compositions and characteristics, including commonly used ingredients as well as alternative recycled/waste materials. The aim of our study was to assess the ability of locally sourced waste materials as roof-growing media amendments. In the greenhouse experiment we tested two grass and herb species mixtures and four waste substrate formulas. The locally disposed waste materials used as components of growing media included silica wastes (byproducts of metallic ferrosilicon alloys), cellulose, foundry sand, and organic waste material removed from the organic horizons of mucky peat. The engineered Si-waste substrates were compared with the commercially available media. The physico-chemical properties of components and substrates, their stability over time, and the influence on plant growth and mineral nutrient status were examined. Particle size distribution, bulk density, mass, water capacity, soil reaction, and total dissolved salt content of Si-waste-growing media were compatible with FLL standards. We found low amounts of available $\mathrm{P}$ and $\mathrm{K}$, and high concentrations of $\mathrm{Ca}, \mathrm{Mg}$, $\mathrm{S}$, and trace elements (with the exception of B) in Si-waste substrates in comparison with the control media. Silica waste materials have the potential to maintain $\mathrm{pH}$ with high buffering capacity. Engineered Si-waste substrates had a positive impact on plant growth and biomass. In general, these results indicate that contaminant elements contained in alkaline Si-waste substrates were not easily available to the root system, and consequently they did not restrict plant growth. We consider Si-wastes to be a valuable and environmentally responsible green roof media amendment.
\end{abstract}

Keywords: bulk density, water capacity, organic matter, trace elements, plant nutrient status

*e-mail: anna_krawczyk@onet.pl 


\section{Introduction}

Roof gardens represent a unique system that can contribute to urban sustainability and well-being in cities. They are especially effective in dense agglomerations with dramatically limited green space availability. Generally, an urban ecosystem is characterized by challenging environmental conditions for growth and development of plants with excessive moisture as well as periods of drought, raised temperature, high light and windspeed intensity, and the risk of dessication and physical damage to plants and substrate [1].

The two main types of roof garden include an extensive and intensive green system. An extensive roof is characterized by a lower depth of substrate $(2-20 \mathrm{~cm})$, which supports succulent plants and herbs with shallow root systems and high resistance to drought. An extensive green roof system is low maintenance and more suitable for a range of buildings types [2]. It is usually designed to have an ecological rather than esthetic function. The growing substrate is one of the most important parts of an extensive green roof system. Choosing the right substrate formulas is crucial because it guarantees the survival of plants and the stability of their population. Today it is possible to use as the roof substrate both natural soil and engineering substrates [3]. The suitability of rooftop substrates is mostly mineral-based, with a small amount of organic components [4]. A number of studies have been carried out to develop appropriate recipes for substrate composition [2, 5-7]. A typical roof substrate consists of $70-95 \%$ of mineral fractions with organic materials and slow-release fertilizer [8]. An adequate amount of light and porous mineral particles such as pumice, lava, expanded clay, shale and slate, volcanic ash, perlite, and coarse sand can provide low substrate density and permeability [9]. A small amount $(2-10 \%)$ of organic materials in the form of compost or peat usually is added to improve substrate nutrient and water capacity $[1,8]$. Green roof media need to provide not only a stable structure promoting plant anchorage but also nutrition to support a healthy plant community. Most lightweight substrates with coarse texture and low organic matter content require water and nutrient supplementation for maintaining major plant growth functions [10].

Characteristics of materials for roof substrates have been included in the German Landscape Research, Development, and Construction Society [11]. Within the living roof industry, FLL tests are currently more widely used than standard agronomic testing, particularly as a marketing tool [3].

Currently, there is growing interest in the use of waste/ recycled materials to reduce the negative impacts of waste on the environment and human health. The wastebased substrates are relatively cheap in comparison to the industry standard media that are generally composed from modified or imported minerals. Recycled material that are often used for commercial green roof substrates include crushed bricks or tiles, crushed concrete, and subsoil [4]. Using these waste materials may reduce transport costs and turn locally landfilled low-value materials into a useful substrate component [9].

Relatively little has been published on the possibility of using waste materials for green roof substrate composition. Carson et al. [2] examined many recycled substrates created from waste drywall, concrete, roof shingles, glass, and lumber cuttings by processing these materials into aggregate form. Promising results showed that waste materials - especially aggregate from concrete - may cause significantly more structural loading than other commercial substrates. Molineux et al. [5] indicated the great potential of locally sourced alternative materials such as crushed red brick pellets (made from clay and sewage sludge), paper ash (from recycled newspapers), and carbonated limestone for engineered green roof substrates. Solano et al. [12] examined media with recycled tire rubber crumb as a lightweight material for amending green roof substrate. Nevertheless, each individual component will affect chemical and physical characteristics of growing media. Waste materials can contain many elements that are both beneficial and potentially toxic for plants.

Before any source can be considered valuable for growing media uses, it should meet a number of criteria, such as suitable physical and chemical properties and especially be free of, or have tolerably low levels of contaminants [13-14].

Nutrients cycling and their availability to biota are key factors in regulating the structure and function of every ecosystem [8]. Due to the challenging environmental conditions on the green rooftop, providing support of beneficial elements can improve plant resistance to both abiotic and biotic stress. Beneficial elements can compensate for toxic effects of other elements or may substitute mineral nutrients in some other less specific function [15]. Although silicon has not been considered an essential nutrient for plants, due to the more widely reported beneficial effects of crops, terms such as "agriculturally essential" or "almost essential" have been used recently [16]. The importance of silicon to plants increases under stress conditions, as it takes part in building the mechanisms of resistance to biotic and abiotic factors [15]. Research demonstrates that low-cost silica wastes can be a valuable source of silicon for plants on Si-deficient growing media $[13,17]$. Silica wastes such as silica fume or silica slag have very high content of amorphous silicon dioxide and are more easily solubilized than crystalline silica [18]. However, Si waste materials as an industrial by-product carry the risk of polluting growing media or otherwise affecting plant growth and development. We hypothesize that Si-rich wastes may have such agronomic value as a silicon plant promoter that enhance growth and resistance to stress in very specific rooftop environmental conditions.

Considering the possibility of using Si waste materials from landfills, the aim of our study was to assess the ability of locally sourced wastes as an addition to the green roof substrate. We quantified and compared benefits of green roof substrate engineered from waste/recycled materials with commercially available media. The physico-chemical 
properties of components and substrates, their stability over time, and influence on plant growth and mineral nutrient status were examined.

\section{Materials and Methods}

\section{Material and Experimental Design}

The study was carried out under controlled conditions at the cold greenhouse in the Experimental Station of the University of Agriculture in Krakow (50 5'3.79'N, $\left.19^{\circ} 57^{\prime} 2.16^{\prime} \mathrm{E}\right)$. The experiment was established on a stimulated, triple-layered, extensive vegetated roof with an approximate substrate layer of $6 \mathrm{~cm}$. Perforated trays with $1.0 \mathrm{~m}$ long and $0.5 \mathrm{~m}$ wide were filled with different waste substrates (types I-IV) and commercial substrate made by Optigreen E-type (control). Characteristics of waste materials are presented in Table 1. Used landfilled silica wastes were a by-product of metallic ferrosilicon alloys. The waste material named Si-waste I was represented by blast furnace slag from cleaning blast furnace, Si-waste II material was blast furnace slag with other residues such as filter powders (silica fume) deposited over a few years in a landfill site, and Si-waste III material - the same by-products from the production of ferrosilicon after many years of being deposited in a landfill. The stones and gravel were mechanically

Table 1. Some physical and chemical properties of waste materials used as a component of green roof substrates.

\begin{tabular}{|c|c|c|c|c|c|c|c|c|}
\hline $\begin{array}{l}\text { Component/ } \\
\text { parameter }\end{array}$ & Si waste I & Si waste II & $\begin{array}{c}\text { Si waste } \\
\text { III }\end{array}$ & $\begin{array}{c}\text { Muck } \\
\text { soil I }\end{array}$ & $\begin{array}{l}\text { Muck } \\
\text { soil II }\end{array}$ & Sand & $\begin{array}{l}\text { Silica } \\
\text { fume }\end{array}$ & Celullose \\
\hline $\mathrm{pH}$ & 8.22 & 7.86 & 9.48 & 4.72 & 4.72 & 6.91 & 7.56 & 7.49 \\
\hline $\mathrm{EC}\left(\mathrm{mS} \mathrm{cm}^{-1}\right)$ & 0.15 & 0.16 & 0.23 & 0.27 & 0.27 & 0.56 & 0.19 & 0.66 \\
\hline Bulk density $\left(\mathrm{g} \mathrm{cm}^{-3}\right)$ & 1.81 & 1.50 & 1.75 & 0.24 & 0.27 & 1.48 & 0.07 & 0.38 \\
\hline Water capacity (\%) & 19.1 & 32.6 & 28.3 & 71.5 & 25.8 & 35.2 & 3.30 & 53.4 \\
\hline Organic matter (\%) & 0.0 & 0.5 & 1.5 & 63.8 & 83.0 & 0.70 & 0.00 & 72.1 \\
\hline \multicolumn{9}{|c|}{ Fractions $(\%)$} \\
\hline$>5 \mathrm{~mm}$ & 87.5 & 66.5 & 55.5 & & & \multirow{6}{*}{ 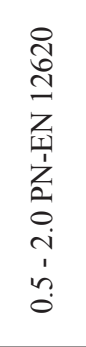 } & & \\
\hline $5-3$ & 7.5 & 7.8 & 10.5 & & & & & \\
\hline $3-2$ & 6.8 & 3.0 & 4.0 & & & & & \\
\hline $2-1$ & 7.5 & 0.8 & 4.0 & & & & & \\
\hline $1-0.3$ & 0.6 & 8.3 & 21.5 & & & & & \\
\hline$<0.06$ & 0.5 & 3.3 & 4.5 & & & & & \\
\hline \multicolumn{9}{|c|}{ Element } \\
\hline $\mathrm{P}\left(\mathrm{mg} \mathrm{dm} \mathrm{dm}^{-3}\right)$ & 1.25 & 4.4 & 5.0 & 0.27 & 2.78 & 0.63 & 114 & 2.64 \\
\hline $\mathrm{K}\left(\mathrm{mg} \mathrm{dm^{-3 }}\right)$ & 224 & 123 & 51.7 & 13.2 & 32.3 & 20.5 & 107 & 21.6 \\
\hline $\mathrm{Ca}\left(\mathrm{mg} \mathrm{dm}^{-3}\right)$ & 5,278 & 4,616 & 2,403 & 953 & 1,169 & 322 & 1,240 & 1,922 \\
\hline $\operatorname{Mg}\left(\mathrm{mg} \mathrm{dm}^{-3}\right)$ & 269 & 218 & 90.8 & 97.2 & 207 & 16.7 & 248 & 56.0 \\
\hline $\mathrm{S}\left(\mathrm{mg} \mathrm{dm} \mathrm{dm}^{-3}\right)$ & 52.2 & 42.1 & 35.9 & 209 & 124 & 23.1 & 46 & 215 \\
\hline $\mathrm{B}\left(\mathrm{mg} \mathrm{kg}^{-1}\right)$ & 11.5 & 4.40 & 1.94 & 6.06 & 6.01 & 0.23 & 1.9 & 5.4 \\
\hline $\mathrm{Cu}\left(\mathrm{mg} \mathrm{kg}^{-1}\right)$ & 119.7 & 89.0 & 45.5 & 5.80 & 5.45 & 7.8 & 47 & 14 \\
\hline $\mathrm{Fe}\left(\mathrm{mg} \mathrm{kg}^{-1}\right)$ & 3,982 & 2,691 & 1,520 & 2,520 & 2,234 & 1,012 & 1,406 & 890 \\
\hline $\operatorname{Mn}\left(\mathrm{mg} \mathrm{kg}^{-1}\right)$ & 8,257 & 2,603 & 2,706 & 178 & 167 & 169 & 1,246 & 52 \\
\hline $\mathrm{Zn}\left(\mathrm{mg} \mathrm{kg}^{-1}\right)$ & 1,082 & 516.7 & 73.3 & 30.7 & 29.5 & 8.0 & 118 & 85 \\
\hline As $\left(\mathrm{mg} \mathrm{kg}^{-1}\right)$ & 10.5 & 3.55 & 2.68 & 4.26 & 4.12 & 1.01 & 10.8 & 3.21 \\
\hline $\mathrm{Cd}\left(\mathrm{mg} \mathrm{kg}^{-1}\right)$ & 4.61 & 2.08 & 0.00 & 1.28 & 1.11 & trace & 19.8 & 0.30 \\
\hline $\mathrm{Cr}\left(\mathrm{mg} \mathrm{kg}^{-1}\right)$ & 23.7 & 11.4 & 6.68 & 0.42 & 0.38 & 2.49 & 8.7 & 0.41 \\
\hline $\mathrm{Ni}\left(\mathrm{mg} \mathrm{kg}^{-1}\right)$ & 12.7 & 13.0 & 5.78 & 15.1 & 14.8 & 1.41 & 3.2 & 0.71 \\
\hline $\mathrm{Pb}\left(\mathrm{mg} \mathrm{kg}^{-1}\right)$ & 254 & 128 & 28.5 & 24.0 & 22.7 & 4.39 & 104 & 9.53 \\
\hline
\end{tabular}


crushed to reduce the size of large fragments and to produce particles $<20 \mathrm{~mm}$. Then the fragments are screened and blended with other components. Organic matter content was added into the substrates in the form of muck soil I and II, and organic waste material was removed from the organic horizons of mucky peat. Waste substrates were also supplemented with foundry sand, waste cellulose, and silica fumes. Silica fumes were generated by electric arc furnaces as a byproduct of ferrosilicon alloys.

The substrate composition of the particular ingredients is shown in Table 2.

The proportion of substrate components was quantified by volume based on requirements and guidelines of German FLL standards. The greenhouse study consisted of two species combinations ('grass mix' and 'herbs mix') and five substrate formulas, including control growing media. Plant selections are typically alpine-type since they are usually drought- and heat tolerant (Table 3). Plant mixture seeds were sown on 1 May 2013 at rate of $0.33 \mathrm{~g} \mathrm{~m}^{-2}$ of 'grass mix' and $1.16 \mathrm{~g} \mathrm{~m}^{-2}$ of 'herbs mix' according to the producer recommendations.

Plants were grown until the end of September 2013. The temperature in the greenhouse was maintained at $18^{\circ} \mathrm{C}$ on cloudy days, $28^{\circ} \mathrm{C}$ on sunny days, and $12^{\circ} \mathrm{C}$ at night. They were watered manually once a week or more often at an advanced stage of growth with the same water amount. Plants were fertilized two times during the growing season with a solution of Yara Mila Complex multicomponent fertilizer (12N:11P:18K:2.7Mg:8S).

\section{Component/Substrate Analyses}

Substrate analyses were determined before and after the vegetation period. Particle size analysis was performed using 5, 3, 2, 1, 0.3, and $0.06 \mathrm{~mm}$ [11] sieves, and bulk density and water capacity using Kopecky's cylinders method [19] and by the Bagg-Olsen method [20]. Water permeability was estimated using Święcicki's method [19]. The content of available macroelements was detected by extraction using $0.03 \mathrm{~mol} \mathrm{dm}^{-3} \mathrm{CH}_{3} \mathrm{COOH}$ solution. The

Table 2. Waste/recycled material components content (\%) in prepared roof substrates.

\begin{tabular}{|c|c|c|c|c|}
\hline \multirow{2}{*}{ Component } & \multicolumn{4}{|c|}{ Content (\%) } \\
\cline { 2 - 5 } & I & II & III & IV \\
\hline Sand & 20 & 30 & 10 & 30 \\
\hline Si waste I & 30 & 30 & 20 & 10 \\
\hline Si waste II & 10 & 20 & 5 & - \\
\hline Si waste III & - & - & 30 & 25 \\
\hline Muck soil I & 30 & - & 25 & - \\
\hline Muck soil II & - & 15 & - & 25 \\
\hline Cellulose & 5 & 5 & 5 & 5 \\
\hline Silica fume & 5 & - & 5 & 5 \\
\hline
\end{tabular}

contents of micro- and trace elements were determined used Rinkis method with extraction of $1 \mathrm{~mol} \mathrm{dm}^{-3} \mathrm{HCl}$ [20]. This technique with relatively "aggressive extractant" removed more than the soluble, exchangeable, and weakly adsorbed fractions. This soil test is currently used to estimate availability and critical levels for available micronutrients in Poland. The components after extraction were analyzed with an inductively coupled plasma optical emission spectrometer (ICP-OES; Prodigy Teledyne Leeman Labs). Soil reaction $(\mathrm{pH})$ and total concentration of salt (EC) were determined in a 1:2 soil:water solution [20], and we estimated the organic matter content by loss on ignition method (in $550^{\circ} \mathrm{C}$ ). The same procedure was used for determining physical and chemical properties of media components.

\section{Plant Analyses}

After 150 days, the above-ground parts of the plants were harvested and weighed. Dry matter content was determined at $105^{\circ} \mathrm{C}$. The plants were dried at $65^{\circ} \mathrm{C}(24 \mathrm{~h})$ and then ground. The plant content of $\mathrm{P}, \mathrm{K}, \mathrm{Ca}, \mathrm{Mg}, \mathrm{S}, \mathrm{Na}$, $\mathrm{B}, \mathrm{Cu}, \mathrm{Fe}, \mathrm{Mn}, \mathrm{Zn}, \mathrm{Cd}, \mathrm{Ni}, \mathrm{Pb}$, and $\mathrm{Cr}$ was determined after mineralization in $65 \%$ extra pure $\mathrm{HNO}_{3}$ in a CEM MARS5 Xpress microwave system, using a high-dispersion ICPOES spectrometer. The leaf $\mathrm{N}$ content was assayed by the Kjeldahl method using a VELP Scientifica UDK 193 distillation unit [20].

\section{Statistical Analyses}

The experiment was arranged as a randomized complete block design in four replications. Statistical analyses were performed using STATISTICA 10.PL (StatSoft Inc., USA). A one-way analysis of variance was used to determine the main effects of the study. To determine the significance between means we used the

Table 3. The composition of plant species seeds in the Optigreen mix.

\begin{tabular}{|c|c|}
\hline 'Herbs mix' - E-Herbs & 'Grass mix' \\
& - E-Grass \\
\hline Achillea millefolium, Allium & \\
schoenoprasum, Anthemis tinctoria, & \\
Aster amellus, Campanula rotundifolia, & \\
Centaurea scabiosa, Dianthus & \\
carthusianorum, D. deltoides, Erodium & Anthoxanthum \\
cicutarium, Fragaria vesca, Galium & odoratum, Briza \\
verum, Geranium robertianum, & media, Bromus \\
Hieracium aurantiacum, H. pilosella,, & tectorum, Festuca \\
Leucanthemum vulgare, Linaria & cinerea, F. ovina \\
vulgaris, Linum perenne, Origa- & wild, \\
num vulgare, Petrorhagia saxifrage, & F. pallens, \\
Potentilla argentea, Prunella gran- & F. rupicola, \\
diflora, P. Vulgaris, Ranunculus & Melica ciliate, \\
bulbosus, Sanguisorba minor, Saponaria & Phleum phleoides \\
ocymoides, S. officinalis, Silene nutans, & \\
Silene otites, Thymus pulegioides, & \\
T. serpyllum & \\
\hline
\end{tabular}


HSD Tukey test. Tests were considered significant at a level below $0.05(p<0.05)$.

\section{Results and Discussion}

\section{Media Components Analysis}

Original $\mathrm{Si}$-waste materials not containing ( $\mathrm{Si}$ waste I) or containing a low amount (Si waste II and III) of organic matter were P- and $\mathrm{N}$ deficient. The $\mathrm{pH}$ of Siwaste components were alkaline ( $\mathrm{pH} 7.86-9.48)$, and they contained high amounts of $\mathrm{Ca}$ and $\mathrm{Mg}$, and elevated levels of $\mathrm{Cu}, \mathrm{Mn}, \mathrm{Zn}$, and $\mathrm{Pb}$ - especially the Si waste I material from blast furnace cleaning, and $\mathrm{Si}$ waste II (Table 1). Muck soils I and II were characterized by high content of S. Sand and cellulose contained low levels of macro-, micronutrients, and trace elements.

\section{Substrate Physical Analysis}

Bulk density of waste substrates ranged from 0.88 to $1.17 \mathrm{~g} \mathrm{dm}^{-3}$, and their mass at a depth of $6 \mathrm{~cm}$ varied from 52.7 to $70.3 \mathrm{~kg} \mathrm{~m}^{-2}$. The control media had bulk density $1.04 \mathrm{~g} \mathrm{dm}^{-3}$ and mass $62.2 \mathrm{~kg} \mathrm{~m}^{-2}$ (Table 4). During six months of vegetation in greenhouse conditions these substrate parameters did not change significantly.
According to FLL standards [11], a suitable dry bulk density range of 0.6 to $1.2 \mathrm{~g} \mathrm{~cm}^{-3}$, and at the bulk density of $1.0 \mathrm{~g} \mathrm{~cm}^{-3}$, a $1 \mathrm{~cm}$ depth of growing media would weigh $10 \mathrm{~kg} \mathrm{~m}^{-2}$.

Water capacity in waste-based media and control substrate was similar and acceptable by FLL norms and ranged from $47.7 \%$ (substrate II) to $50.7 \% \mathrm{wv}$ (substrate III) (Table 4). According to the German standards [11], multi-layer extensive substrate type should have a maximum water capacity within $\geq 35 \leq 65 \%$ wv. Green roof substrates should demonstrate maximum rainwater capacity in a vegetation layer, but at the same time should be able to guarantee runoff excess into the drainage layer [3]. The results of the presented study showed a decrease of water-holding capacity during the relatively short growing season in the greenhouse, particularly in waste substrates. The form of organic matter added to substrate may affect water-holding capacity due to different absorption properties. It should be noted that even small changes to organic composition or quantity as a result of microbial decomposition or recycling of biomass of roots may have great impact on substrate water properties, which was confirmed by the studies of Emilsson [9], Young et al. [7], and Ondoño et al. [21].

Water permeability of the waste substrates determined after the growing season reached values $0.02-0.04 \mathrm{~cm} \mathrm{~s}^{-1}$, and was significantly lower than for the control treatment

Table 4. Some physical and chemical properties of prepared roof substrates before and after planting.

\begin{tabular}{|c|c|c|c|c|c|}
\hline Substrate & Growing season & $\begin{array}{l}\text { Bulk density } \\
\mathrm{g} \mathrm{cm}^{-3}\end{array}$ & $\begin{array}{c}\text { Mass } \\
\mathrm{kg} \mathrm{m}^{-2 *}\end{array}$ & $\begin{array}{c}\text { Organic matter } \\
\%\end{array}$ & $\begin{array}{c}\text { Water capacity } \\
\% \mathrm{wV}\end{array}$ \\
\hline \multirow{2}{*}{ Control } & before & $1.04 \mathrm{~b}$ & $62.2 \mathrm{~b}$ & $8.3 \mathrm{a}$ & $45.6 \mathrm{a}$ \\
\hline & after & $0.92 \mathrm{a}$ & $55.2 \mathrm{a}$ & $10.8 \mathrm{~b}$ & $51.0 \mathrm{~b}$ \\
\hline \multirow{2}{*}{ I } & before & $0.90 \mathrm{a}$ & $54.0 \mathrm{a}$ & $7.3 \mathrm{a}$ & $57.1 \mathrm{~b}$ \\
\hline & after & $1.17 \mathrm{~b}$ & $69.9 \mathrm{~b}$ & $9.6 \mathrm{~b}$ & $42.6 \mathrm{a}$ \\
\hline \multirow{2}{*}{ II } & before & 1.13 & 67.8 & $6.8 \mathrm{a}$ & $49.3 \mathrm{~b}$ \\
\hline & after & 0.88 & 52.7 & $9.4 \mathrm{~b}$ & $46.2 \mathrm{a}$ \\
\hline \multirow{2}{*}{ III } & before & 1.02 & 61.2 & 6.3 & $54.0 \mathrm{~b}$ \\
\hline & after & 1.06 & 63.4 & 7.9 & $47.3 \mathrm{a}$ \\
\hline \multirow{2}{*}{ IV } & before & $1.01 \mathrm{a}$ & $60.6 \mathrm{a}$ & 6.8 & $55.4 \mathrm{~b}$ \\
\hline & after & $1.17 \mathrm{~b}$ & $70.3 \mathrm{~b}$ & 7.5 & $40.4 \mathrm{a}$ \\
\hline \multirow{2}{*}{ Mean period } & before & 1.02 & 61.2 & $6.3 \mathrm{a}$ & $52.3 \mathrm{~b}$ \\
\hline & after & 1.04 & 62.3 & $9.0 \mathrm{~b}$ & $45.5 \mathrm{a}$ \\
\hline \multirow{5}{*}{ Mean substrate } & Control & 0.98 & 58.7 & $9.5 \mathrm{c}$ & 48.3 \\
\hline & I & 1.03 & 62.0 & $8.4 \mathrm{bc}$ & 49.8 \\
\hline & II & 1.00 & 60.3 & $6.2 \mathrm{a}$ & 47.7 \\
\hline & III & 1.04 & 62.3 & $7.1 \mathrm{ab}$ & 50.7 \\
\hline & IV & 1.09 & 65.5 & $7.1 \mathrm{ab}$ & 47.9 \\
\hline
\end{tabular}




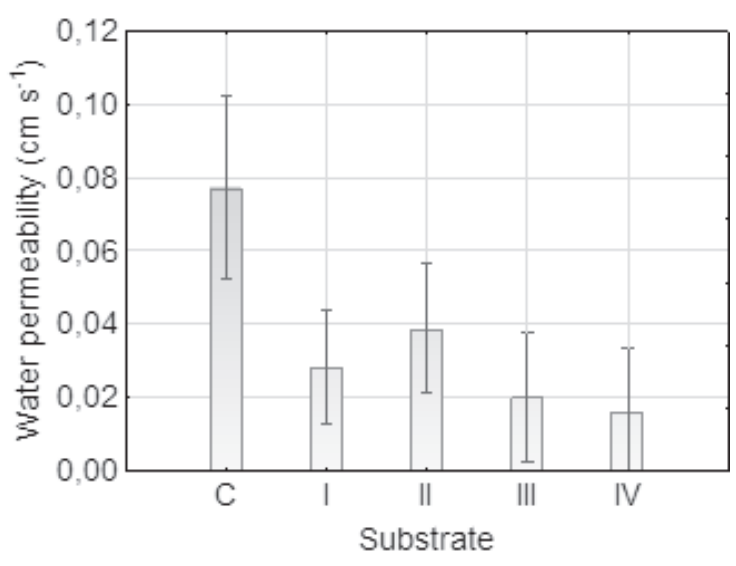

Fig. 1. Water permeability $\left(\mathrm{cm} \mathrm{s}^{-1}\right)$ of substrates after planting.

$\left(0.08 \mathrm{~cm} \mathrm{~s}^{-1}\right)$ (Fig. 1). This might be linked to the addition of fine particles $(0.1-0.5 \mu \mathrm{m})$ of silica fumes to waste media. According to Sutton [8], water permeability of extensive type substrates should be approximately 0.001 $\mathrm{cm} \mathrm{s}^{-1}$ (assuming bulk density of $1 \mathrm{~g} \mathrm{~cm}^{-3}$ ). The FLL guidelines target a lab-measured permeability of $\geq 0.001$ $\mathrm{cm} \mathrm{s}^{-1}$ to $\leq 0.1 \mathrm{~cm} \mathrm{~s}^{-1}$ for extensive roofs.

In the presented study, the highest organic matter content $(9.5 \%)$ was found in the commercial control media, while the content of organic matter in examined waste substrates was generally lower (Table 4). Oberndorfer et al. [1] showed that the right organic matter content in extensive green roof growing media should be about $10 \%$ by weight. High amounts of organic matter can lead to substrate volume shrinkage and increased nutrient loss in runoff as a result of microbial decomposition $[4,10]$. According to German standards [11], the minimum content of organic matter in the roof substrate is $4 \%$ for single-layer systems in the extensive type, and up to $10 \%$ in intensive systems. Sutton [8] demonstrated that the preferred value is $6.5 \%$ of organic matter. Generally, plant growth is greater in media with a high content of organic matter, but lush vegetation may result in damage during drought [6]. On the other hand, increased organic matter content contributed to increased water-holding capacity and consequently increased weight on the roof $[8,22]$. However, Molineux et al. [5] found that the addition of organics reduced the $\mathrm{pH}$ of the recycled aggregates, making growing conditions for plants more favorable. In relation to the initial values, we observed a significant increase in the organic matter content in all substrates - including the control media at the end of the experiment (Table 4). Similar results were found by Schrader and Böning [23] and Köhler and Poll [24], who reported increased $\mathrm{C}$ organic and total $\mathrm{N}$ in older roof substrate. This phenomenon might be related to the development of a large mass of plant roots. Plants interact with their environment, actively influencing the rhizosphere by chemical secretions. Plant litter and microbiological activity mediated physical and chemical processes and contributed organic matter to the soil [23, 25]. This clearly demonstrated that soil-forming processes during roof substrate maturation lead to increased organic matter and biological activity.

German recommendations also specify requirements of the granulation composition of the roof substrate. The content of the particles with a diameter of $\leq 0.063 \mathrm{~mm}$ in substrate for extensive roofs should not exceed $15 \%$ by weight $[8,11]$. The high content of clay and silt fractions in excessive humidity cause strong plasticity and stickiness. Restrictions of air and water movement largely limit expansion of the root system of plants [8]. In our investigations, all waste substrates have a small amount of fine particles $(<0.06 \mathrm{~mm})$, not exceeding the recommended level by FLL standards (Table 5).

\section{Substrate Chemical Analysis}

According to the FLL standard [11], the optimum $\mathrm{pH}$ of growing substrates that guarantees nutrient uptake by plants ranges 6.5-9.5 for an extensive roof system. The $\mathrm{pH}$ analysis for waste substrates I-IV before planting has revealed that all the growing media is slightly acid to neutral (pH 6.21-6.93). The industry standard had higher $\mathrm{pH}$ (7.85) in accordance with FLL guidelines. After the growing season, $\mathrm{pH}$ increased significantly to 7.61-7.98 in waste substrate and 8.10 for control (Table 6). Ampim et al. [4] indicated that higher $\mathrm{pH}$ substrates may be useful in areas with acid rainfall events. However, extreme values of $\mathrm{pH}$ could severely restrict plant growth [8]. According to Molineux et al. [5], the addition of organic matter could reduce $\mathrm{pH}$ for a variety of recycled alkaline substrates and bring each component closer to FLL requirements. On the other hand, in alkaline growing media the availability and phytotoxicity of certain trace elements such as $\mathrm{Pb}, \mathrm{Cd}$, and $\mathrm{Ni}$ is severely limited [26].

Table 5. Particle size distribution of prepared roof substrates after planting.

\begin{tabular}{|c|c|c|c|c|c|c|c|}
\hline \multirow{2}{*}{ Substrate } & \multicolumn{7}{|c|}{$\%$ fractions (diameter mm's) } \\
\hline & $>5$ & $5-3$ & $3-2$ & $2-1$ & $1-0.03$ & $0.3-0.006$ & $<0.06$ \\
\hline Control & 31.4 & 9.3 & 8.6 & 3.3 & 17.3 & 23.3 & 0.6 \\
\hline I & 43.2 & 5.9 & 7.9 & 4.1 & 20.8 & 17.3 & 1.0 \\
\hline II & 31.5 & 5.5 & 8.1 & 4.5 & 24.6 & 18.8 & 1.0 \\
\hline III & 28.0 & 5.7 & 9.4 & 5.8 & 24.2 & 21.2 & 0.6 \\
\hline IV & 31.8 & 3.8 & 8.1 & 4.0 & 24.4 & 22.4 & 1.3 \\
\hline
\end{tabular}


The total dissolved salt content in the substrate should not exceed $3.5 \mathrm{~g} \mathrm{dm}^{-3}$ by extensive greening [11]. In the presented study, total salt concentration of all substrates, expressed as electrical conductivity (EC) of soil solution, was much lower than the maximum acceptable level $\left(2 \mathrm{mS} \mathrm{cm}^{-1}\right)$ and ranged from 0.24 (control) to $0.35 \mathrm{mS} \mathrm{cm}^{-1}$ (waste substrate I; Table 6). Total dissolved salt content was significantly lower at the end of the growing season.

According to FLL standards [11] the nutrient content of extensive roof substrates needs to be kept as low as possible and may not exceed the recommended levels (in $\mathrm{mg} \mathrm{dm}{ }^{-3}$ ) of $\mathrm{N} \leq 80, \mathrm{P} \leq 20, \mathrm{~K} \leq 400$, and $\mathrm{Mg} \leq 200$. In our study, soluble forms of macronutrients were detected after extraction with $0.03 \mathrm{~mol} \mathrm{dm}^{-3}$ acetic acid. This procedure is commonly used in Poland for available macronutrient determination in growing media. According to reference values for this soil test $\left(\mathrm{mg} \mathrm{dm}^{-3}: 30 \mathrm{P}, 150 \mathrm{~K}, 1000 \mathrm{Ca}\right.$, $60 \mathrm{Mg},<20 \mathrm{~S}_{-} \mathrm{SO}_{4}$ ), we found low amounts of available $\mathrm{P}$ and $\mathrm{K}$, and high concentrations of $\mathrm{Ca}, \mathrm{Mg}$, and $\mathrm{S}$ (Table 5). The concentrations of $\mathrm{K}, \mathrm{Ca}, \mathrm{Mg}$, and $\mathrm{S}$ significantly varied and depended on substrate formulations. Generally, a high amount of Si-waste I material in the substrate formula increased $\mathrm{K}, \mathrm{Mg}$, and $\mathrm{S}$ concentrations in waste substrates.

Phosphorus content in all waste substrates was significantly higher at the end of vegetation than before planting (Table 6). It is possible that $\mathrm{Si}$ displaced $\mathrm{P}$ from the exchange sites, an increase in $\mathrm{P}$ solubility resulting from an increase in soil $\mathrm{pH}$ and the application of silica fumes, which contained $114 \mathrm{mg} \mathrm{P} \mathrm{dm}^{-3}$ of waste.

With the exception of waste substrate III, with increasing $\mathrm{pH}$ values of growing media during vegetation, $\mathrm{Mg}$ content in substrates also increased. Contrasting this, sulphur concentration in tested substrates was lower after vegetation than before.

Essential elements for plants, such as $\mathrm{B}, \mathrm{Cu}, \mathrm{Mn}, \mathrm{Zn}$, and $\mathrm{Ni}$ often acting as cofactors in biochemical reaction, can be toxic when present in excess. Other trace elements such as $\mathrm{Cd}$ and $\mathrm{Pb}$ have no known biological functions and could be toxic even at very low concentrations [26]. Heavy metals induce oxidative stress and manifest themselves by inhibiting plant growth, lowering chlorophyll content, and causing root injury, leading to reduced nutrient uptake. However, plants are much more resistant to an increased concentration than to an insufficient content of elements [27].

The results showed significantly higher content of trace elements with the exception of boron, in prepared waste substrates in comparison with the control media (Table 7). The concentrations of Fe, Mn, Zn, Cd, Ni, Pb, and $\mathrm{Cr}$ were higher in growing media before planting season than after vegetation. The reverse trend was shown for $\mathrm{Cu}$ content. These results can suggest a reduction in the solubility of metal ions due to the increase in $\mathrm{pH}$ values and $\mathrm{Ca}$ concentration in substrates. Media

Table 6. Soil reaction $(\mathrm{pH})$, salt concentrations $(\mathrm{EC} \mathrm{mS} \mathrm{cm}-1)$, and macronutrient concentrations $\left(\mathrm{mg} \mathrm{dm}^{-3}\right)$ in the substrates before and after planting.

\begin{tabular}{|c|c|c|c|c|c|c|c|c|}
\hline Substrate & Time & $\mathrm{pH}_{\mathrm{H} 2 \mathrm{O}}$ & $\mathrm{EC}$ & $\mathrm{P}$ & $\mathrm{K}$ & $\mathrm{Ca}$ & $\mathrm{Mg}$ & $\mathrm{S}$ \\
\hline \multirow{3}{*}{ Control } & before & $7.85 \mathrm{a}$ & $0.39 \mathrm{~b}$ & 8.6 & 36 & 2,725 & 40.3 & 72 \\
\cline { 2 - 9 } & after & $8.10 \mathrm{~b}$ & $0.09 \mathrm{a}$ & 6.9 & 30 & 3,706 & 126 & 86 \\
\hline \multirow{3}{*}{$\mathrm{I}$} & before & $6.21 \mathrm{a}$ & $0.48 \mathrm{~b}$ & 2.7 & 72 & 2,805 & 132 & 126 \\
\cline { 2 - 9 } & after & $7.86 \mathrm{~b}$ & $0.21 \mathrm{a}$ & 16.6 & 82 & 3,297 & 327 & 106 \\
\hline \multirow{3}{*}{ II } & before & $6.93 \mathrm{a}$ & $0.41 \mathrm{~b}$ & 2.7 & 79 & 4,001 & 173 & 100 \\
\cline { 2 - 9 } & after & $7.61 \mathrm{~b}$ & $0.22 \mathrm{a}$ & 22.3 & 50 & 1,729 & 194 & 70 \\
\hline \multirow{3}{*}{ III } & before & $6.51 \mathrm{a}$ & $0.41 \mathrm{~b}$ & 8.4 & 55 & 2,055 & 145 & 82 \\
\cline { 2 - 9 } & after & $7.96 \mathrm{~b}$ & $0.18 \mathrm{a}$ & 11.9 & 33 & 1,174 & 140 & 40 \\
\hline \multirow{3}{*}{ IV } & before & $6.40 \mathrm{a}$ & $0.34 \mathrm{~b}$ & 5.1 & 36 & 1,271 & 117 & 81 \\
\cline { 2 - 9 } & after & $7.98 \mathrm{~b}$ & $0.13 \mathrm{a}$ & 7.4 & 35 & 1,293 & 143 & 36 \\
\hline \multirow{3}{*}{ Mean time } & before & $6.78 \mathrm{a}$ & $0.41 \mathrm{~b}$ & $5.5 \mathrm{a}$ & 56 & 2,571 & $122 \mathrm{a}$ & $92 \mathrm{~b}$ \\
\cline { 2 - 9 } & after & $7.90 \mathrm{~b}$ & $0.17 \mathrm{a}$ & $13.3 \mathrm{~b}$ & 46 & 2,113 & $187 \mathrm{~b}$ & $66 \mathrm{a}$ \\
\hline & Control & $7.98 \mathrm{c}$ & $0.24 \mathrm{a}$ & 7.7 & $33 \mathrm{a}$ & $3,216 \mathrm{~b}$ & $83.2 \mathrm{a}$ & $79 \mathrm{ab}$ \\
\hline
\end{tabular}

Values followed by different letters differ significantly, $\mathrm{p}<0.05$. 
Table 7. Trace element $\left(\mathrm{mg} \mathrm{kg}^{-1}\right)$ contents in the substrates before and after planting.

\begin{tabular}{|c|c|c|c|c|c|c|c|c|c|c|}
\hline Substrate & Time & B & $\mathrm{Cu}$ & $\mathrm{Fe}$ & $\mathrm{Mn}$ & $\mathrm{Zn}$ & $\mathrm{Cd}$ & $\mathrm{Ni}$ & $\mathrm{Pb}$ & $\mathrm{Cr}$ \\
\hline \multirow{2}{*}{ Control } & before & 3.4 & 5.4 & 583 & 66 & 18 & 0.14 & 1.3 & 5 & 0.5 \\
\hline & after & 1.9 & 18 & 307 & 37 & 16 & 0.14 & 1.4 & 6 & 1.0 \\
\hline \multirow{2}{*}{ I } & before & 0.1 & 34 & 2,707 & 2,797 & 171 & 1.6 & 6.5 & 91 & 6.0 \\
\hline & after & 1.4 & 40 & 1,521 & 3,244 & 123 & 1.4 & 10.2 & 86 & 6.7 \\
\hline \multirow{2}{*}{ II } & before & 0.7 & 43 & 1,453 & 1,953 & 141 & 1.8 & 9.9 & 100 & 7.5 \\
\hline & after & 0.8 & 11 & 889 & 312 & 43 & 0.48 & 3.3 & 22 & 2.6 \\
\hline \multirow{2}{*}{ III } & before & 1.9 & 69 & 1,893 & 4,853 & 199 & 2.4 & 17.1 & 89 & 9.8 \\
\hline & after & 1.0 & 111 & 1,334 & 1,471 & 78 & 1.0 & 6.2 & 43 & 5.2 \\
\hline \multirow{2}{*}{ IV } & before & 0.3 & 24 & 1,210 & 1,354 & 41 & 0.55 & 7.5 & 19 & 3.6 \\
\hline & after & 0.8 & 115 & 1,127 & 1,408 & 51 & 0.7 & 6.9 & 33 & 5.6 \\
\hline \multirow{2}{*}{ Mean time } & before & 1.1 & $37 \mathrm{a}$ & $1,640 \mathrm{~b}$ & $2,357 \mathrm{~b}$ & $121 \mathrm{~b}$ & $1.4 \mathrm{~b}$ & $9.0 \mathrm{~b}$ & $65 \mathrm{~b}$ & $5.8 \mathrm{~b}$ \\
\hline & after & 1.2 & $59 \mathrm{~b}$ & $1,036 \mathrm{a}$ & $1,294 \mathrm{a}$ & $62 \mathrm{a}$ & $0.74 \mathrm{a}$ & $5.6 \mathrm{a}$ & $38 \mathrm{a}$ & $4.2 \mathrm{a}$ \\
\hline \multirow{5}{*}{ Mean substrate } & Control & $2.4 \mathrm{c}$ & $14 \mathrm{a}$ & 399 a & $46.6 \mathrm{a}$ & $16 \mathrm{a}$ & $0.14 \mathrm{a}$ & $1.3 \mathrm{a}$ & $6 \mathrm{a}$ & $0.8 \mathrm{a}$ \\
\hline & I & $0.9 \mathrm{ab}$ & $37 \mathrm{a}$ & $2,029 \mathrm{~d}$ & $3,052 \mathrm{c}$ & $144 \mathrm{~d}$ & $1.5 \mathrm{~d}$ & $8.6 \mathrm{c}$ & $88 \mathrm{c}$ & $6.4 \mathrm{c}$ \\
\hline & II & $0.8 \mathrm{a}$ & $25 \mathrm{a}$ & $1,131 \mathrm{~b}$ & $1,015 \mathrm{~b}$ & $85 \mathrm{c}$ & $1.0 \mathrm{c}$ & $6.1 \mathrm{~b}$ & $56 \mathrm{bc}$ & $4.7 \mathrm{~b}$ \\
\hline & III & $1.4 \mathrm{~b}$ & $93 \mathrm{~b}$ & $1,573 \mathrm{c}$ & $2,920 \mathrm{c}$ & $47 \mathrm{~b}$ & $1.6 \mathrm{~d}$ & $10.9 \mathrm{~d}$ & $63 \mathrm{c}$ & $7.2 \mathrm{c}$ \\
\hline & IV & $0.6 \mathrm{a}$ & $76 \mathrm{~b}$ & $1,163 \mathrm{~b}$ & $1,385 \mathrm{~b}$ & $47 \mathrm{~b}$ & $0.62 \mathrm{~b}$ & $7.2 \mathrm{bc}$ & $27 \mathrm{ab}$ & $4.7 \mathrm{~b}$ \\
\hline
\end{tabular}

Values followed by different letters differ significantly, $\mathrm{p}<0.05$.

alkaline reactions can contribute to the immobilization of heavy metals, primarily through the formation of carbonates and phosphates, which reduces their toxicity for plants. Moreover, organic matter fixes very strongly $\mathrm{Cr}, \mathrm{Fe}$, and $\mathrm{Pb}$; fairly strongly $\mathrm{Cd}$ and $\mathrm{Ni}$; and only slightly Mn, Zn, and other trace metals [26]. Solano et al. [12] demonstrated that media with high cation exchange capacities can effectively mitigate zinc released from waste materials.

\section{Plant Analysis}

The dry matter content of 'herbs mix' plants grown in the waste substrates ranged from $23.6 \%$ (substrate IV) to $30.6 \%$ (substrate II) in relation to the control ones with $28.1 \%$. The 'grass mix' plants had dry matter content between $22.2 \%$ (substrate I) to $30.0 \%$ (substrate IV), compared to the highest control with $31.6 \%$.

Plant biomass is extremely important for determining plant success on a green roof and is necessary to achieve optimal stormwater retention, aesthetics, and other benefits that green roofs can provide. The biomass production of herbs and grass was significantly higher for Si-waste substrates II-IV than for control treatment (Tables 8-9). Grass biomass collected from waste substrates IV and III was two to three times higher than that collected from control media. Relatively low biomass produced by plants was observed for the growing medium I characterized by the lowest part of the waste mineral fraction $(65 \%)$.
Generally, grass species are considered Si accumulators [15]. Silicon may increase the drought tolerance of plants [14], which is extremely important adaptation for plants grown in extensive green roof conditions. Additionally, the soluble Si can stimulate increased P and Mo uptake by plants, as well as Mn transport within plant tissues [26]. Turnau et al. [28] found that plants originating from xerothermic grasslands are able to grow in industrial wastes rich in high metals concentrations and are tolerant to drought and raised temperatures.

Herbaceous crops from fertilized soils are characterized by concentrations of nitrogen, which exceed $3.0 \% \mathrm{~d} . \mathrm{m}$. of mature leaves. The sufficiency range $\mathrm{N}$ concentration commonly reported for foliage plants is $2.2-3.8 \%$ d.m., and for grasses $2.0-3.2 \%$ d.m. with low value when symptoms of deficiency are shown $<2.2 \%$ and $<1.5 \%$, respectively [29]. In our investigation the content of $\mathrm{N}$ in herbs biomass was lower than the optimal level, especially in Si-waste substrates. The similar low nitrogen status of plants was proved for grass biomass. However, in grass control treatment $\mathrm{N}$ concentration was lower than in substrates I and II. It should be noted that low N concentration in plants grown in waste substrates could be the result of the 'dilution effect' in the highest biomass produced in those treatments.

Phosphorus concentration in 'herb mix' did not vary reliably across treatment and ranged from $0.21 \%$ to $0.29 \% \mathrm{P}$ in dry mass (Table 8 ). In 'grass mix' species we detected from $0.14 \%$ (substrate IV) to $0.21 \% \mathrm{P}$ in d.m 
Table 8. Dry matter (\%) and biomass $\left(\mathrm{g} \mathrm{m}^{-2}\right)$ of 'herbs mix' production in different green roof substrates, and element concentrations (\% d.m.) in plant biomass.

\begin{tabular}{|c|c|c|c|c|c|c|c|c|c|c|}
\hline \multirow{2}{*}{ Substrate } & \multirow{2}{*}{ d.m. $\%$} & \multirow{2}{*}{ Biomass } & \multicolumn{8}{|c|}{$\%$ d.m. } \\
\hline & & & $\mathrm{N}$ & $\mathrm{P}$ & & K & $\mathrm{Ca}$ & $\mathrm{Mg}$ & $\mathrm{S}$ & $\mathrm{Na}$ \\
\hline Control & 28.1 & 338 & 1.82 & 0.21 & & 2.2 & 1.11 & $0.22 \mathrm{ab}$ & $0.13 \mathrm{a}$ & 345 \\
\hline I & 25.0 & 268 & 1.49 & 0.29 & & 2.2 & 1.09 & $0.27 \mathrm{~b}$ & $0.20 \mathrm{~b}$ & 323 \\
\hline II & 30.6 & 364 & 1.45 & 0.21 & & 0.96 & 0.97 & $0.23 \mathrm{ab}$ & $0.18 \mathrm{~b}$ & 328 \\
\hline III & 23.6 & 524 & 1.57 & 0.24 & & 1.9 & 0.85 & $0.20 \mathrm{a}$ & $0.13 \mathrm{a}$ & 534 \\
\hline IV & 24.4 & 382 & 1.54 & 0.21 & & 1.7 & 0.88 & $0.24 \mathrm{ab}$ & $0.15 a b$ & 624 \\
\hline \multirow{2}{*}{ Substrate } & \multicolumn{10}{|c|}{$\mathrm{mg} \mathrm{kg}^{-1}$ d.m } \\
\hline & \multicolumn{2}{|c|}{ B } & $\mathrm{Cu}$ & $\mathrm{Fe}$ & $\mathrm{Mn}$ & $\mathrm{Zn}$ & $\mathrm{Cd}$ & $\mathrm{Ni}$ & $\mathrm{Pb}$ & $\mathrm{Cr}$ \\
\hline Control & \multicolumn{2}{|c|}{$42 \mathrm{~b}$} & $5.2 \mathrm{a}$ & $124 \mathrm{a}$ & $196 \mathrm{a}$ & 72 & $0.79 \mathrm{a}$ & trace & $0.62 \mathrm{a}$ & 0.35 \\
\hline I & \multicolumn{2}{|c|}{$31 \mathrm{ab}$} & $16.8 \mathrm{ab}$ & $373 \mathrm{a}$ & $289 a$ & 71 & $0.82 \mathrm{a}$ & $0.15 \mathrm{a}$ & $2.72 a b$ & 12.0 \\
\hline II & \multicolumn{2}{|c|}{$31 \mathrm{ab}$} & $10.6 \mathrm{a}$ & $\begin{array}{c}482 \\
\text { ab }\end{array}$ & $185 \mathrm{a}$ & 92 & $1.05 \mathrm{ab}$ & $0.44 \mathrm{a}$ & $3.71 \mathrm{ab}$ & 2.30 \\
\hline III & \multicolumn{2}{|c|}{$34 \mathrm{ab}$} & $18.2 \mathrm{ab}$ & $338 \mathrm{a}$ & $122 \mathrm{a}$ & 76 & $1.32 \mathrm{~b}$ & trace & $3.76 \mathrm{ab}$ & 1.78 \\
\hline IV & \multicolumn{2}{|c|}{$28 \mathrm{a}$} & $28.4 \mathrm{~b}$ & $953 \mathrm{~b}$ & $854 \mathrm{~b}$ & 77 & $0.96 \mathrm{ab}$ & $2.04 \mathrm{~b}$ & $5.19 \mathrm{~b}$ & 5.20 \\
\hline
\end{tabular}

Values followed by different letters differ significantly, $\mathrm{p}<0.05$.

(substrate II). Low concentrations of $\mathrm{P}$ in grasses were correlated with low content of available phosphorus in growing media. Barker and Pilbeam [29] reported that the total phosphorus content of the plant is about 0.1 to $1 \%$ and for grasses $(0.20-0.35 \%$ d.m.).

The optimum potassium concentration for fully developed leaves of forage grasses range from 2.5 to $3.5 \%$ d.m. [29]. According to this sufficiency range, in our study $\mathrm{K}$ content in plant biomass was below the optimum level in all treatments, including the control (Table 9). However, species used for the 'grass mix' combination belong to xerothermic plants, which are commonly lownutrient requirements. Turnau et al. [30] found that plants growing on the industrial waste substrates generally had greater concentrations of heavy metals $(\mathrm{Zn}, \mathrm{As}, \mathrm{Pb}$, and $\mathrm{Fe}$ ) and lower concentrations of $\mathrm{K}$ than plants from

Table 9. Dry matter $(\%)$ and the biomass $\left(\mathrm{g} \mathrm{m}^{-2}\right)$ of 'grass mix' $(\mathrm{g})$ production in different green roof substrates, and element concentrations (\% d.m.) in plant biomass.

\begin{tabular}{|c|c|c|c|c|c|c|c|c|c|}
\hline \multirow{2}{*}{ Substrate } & \multirow{2}{*}{ d.m. $\%$} & \multirow{2}{*}{ Biomass } & \multicolumn{7}{|c|}{$\%$ d.m. } \\
\hline & & & $\mathrm{N}$ & $\mathrm{P}$ & $\mathrm{K}$ & $\mathrm{Ca}$ & $\mathrm{Mg}$ & $\mathrm{S}$ & $\mathrm{Na}$ \\
\hline Control & $31.6 \mathrm{~b}$ & 182 & 1.35 & $0.18 \mathrm{ab}$ & $1.9 \mathrm{ab}$ & $0.82 \mathrm{~b}$ & 0.18 & $0.12 \mathrm{ab}$ & 287 \\
\hline I & $22.2 \mathrm{a}$ & 152 & 1.45 & $0.20 \mathrm{ab}$ & $2.0 \mathrm{~b}$ & $0.53 \mathrm{ab}$ & 0.15 & $0.16 \mathrm{~b}$ & 630 \\
\hline II & $24.0 \mathrm{ab}$ & 336 & 1.45 & $0.21 \mathrm{~b}$ & $1.9 \mathrm{ab}$ & $0.57 \mathrm{ab}$ & 0.15 & $0.14 \mathrm{ab}$ & 581 \\
\hline III & $27.5 \mathrm{ab}$ & 534 & 1.32 & $0.16 \mathrm{ab}$ & $1.5 \mathrm{a}$ & $0.37 \mathrm{a}$ & 0.11 & $0.08 \mathrm{a}$ & 594 \\
\hline IV & $30.0 \mathrm{ab}$ & 438 & 1.28 & $0.14 \mathrm{a}$ & $1.5 \mathrm{a}$ & $0.38 \mathrm{a}$ & 0.12 & $0.08 \mathrm{a}$ & 459 \\
\hline \multirow{2}{*}{ Substrate } & \multicolumn{9}{|c|}{$\mathrm{mg} \mathrm{kg}^{-1}$ d.m } \\
\hline & B & $\mathrm{Cu}$ & $\mathrm{Fe}$ & $\mathrm{Mn}$ & $\mathrm{Zn}$ & $\mathrm{Cd}$ & $\mathrm{Ni}$ & $\mathrm{Pb}$ & $\mathrm{Cr}$ \\
\hline Control & 17.8 & 5.5 & 120 & $28 \mathrm{a}$ & 54 & $0.65 \mathrm{a}$ & trace & 0.8 & $1.1 \mathrm{ab}$ \\
\hline I & 8.7 & 7.8 & 217 & $77 \mathrm{ab}$ & 38 & $0.83 \mathrm{ab}$ & trace & 1.3 & $1.6 \mathrm{ab}$ \\
\hline II & 8.7 & 7.0 & 156 & $59 \mathrm{ab}$ & 42 & $0.67 \mathrm{a}$ & trace & 2.2 & $2.5 \mathrm{~b}$ \\
\hline III & 4.8 & 12.9 & 144 & $102 \mathrm{~b}$ & 37 & $1.2 \mathrm{~b}$ & trace & 1.7 & $0.75 \mathrm{a}$ \\
\hline IV & 4.7 & 7.8 & 145 & $105 \mathrm{~b}$ & 34 & $0.88 \mathrm{ab}$ & trace & 1.65 & $0.54 \mathrm{a}$ \\
\hline
\end{tabular}

Values followed by different letters differ significantly, $\mathrm{p}<0.05$. 
natural xerothermic grasslands. The authors concluded that K-supplementation of the waste substrates should be considered to improve plant growth.

Among all nutrients detected, $\mathrm{Ca}$ prevailed in the plant material. Generally, grasses showed much lower concentrations of Ca when compared to 'herb mix' species from all substrate root environments. Its concentration ranged from $0.38 \%$ in 'grass mix' substrate III to over $1 \%$ in the control 'herb mix' (Tables 8-9). The Ca concentration in plants varies between $0.1 \%$ and $5 \%$ of dry weight [29]. As shown in the present study, plants from control treatment contained more $\mathrm{Ca}$ when growing in the waste substrates. These results are in close agreement with those reported by Turnau et al. [30]. Silicon may affect the bioavailability of $\mathrm{Ca}$ for plants.

Significantly higher $\mathrm{Cu}, \mathrm{Fe}, \mathrm{Cd}, \mathrm{Pb}, \mathrm{Cr}$, and Ni contents were identified in plant tissues from waste substrates than from control samples (Tables 8-9). On average, a relatively low concentration of potentially toxic metals was characteristic for grasses. High concentrations of $\mathrm{Zn}$ in relation to the control were noted only in plants from the 'herb mix' growing in substrate II. Silicon can alleviate heavy metal toxicity in plants at both plant and soil levels $[15,31]$. It should be noted that reduced uptake of metals after silica wastes amendment can be attributed to an increase in soil $\mathrm{pH}$ and changes in metal speciation in the growing media. This may explain the high production of biomass in substrates based on silicon waste with averagehigh concentrations of heavy metals.

The boron content in plants collected from Si-waste substrates was relatively low in relation to control plants (Tables 8-9). The possible explanation for this phenomenon is the antagonistic effect of $\mathrm{Si}$ on the uptake of $\mathrm{B}$ [26].

Manganese content in 'herb mix' plants was higher than in grasses and ranged from $122 \mathrm{mg}$ to $289 \mathrm{mg} \mathrm{kg}^{-1}$ d.m., and from $28 \mathrm{mg}$ to $102 \mathrm{mg} \mathrm{kg}^{-1}$, respectively. Mengel and Kirkby [32] demonstrate that Mn amounts of less than $20 \mathrm{mg} \mathrm{kg}^{-1} \mathrm{~d}$.m is insufficient for most of the plant species, 20-500 mg kg-1 is optimal, and concentrations exceeding $500 \mathrm{mg} \mathrm{kg}^{-1}$ d.m are toxic. The substrate chemical composition with particularly high concentrations of available Mn had low impact on manganese concentration in plant tissues. Kabata-Pendias [26] demonstrate the ameliorative effect of available Si on reducing the toxicity of $\mathrm{Al}$ and $\mathrm{Mn}$ by immobilizing these elements at the root surface. Si increases Mn binding to cell walls, which limits cytoplasmic concentrations [15].

\section{Conclusions}

Currently, a need to identify suitable locally available waste products is a growing concern, as the import of lightweight minerals or using processed cost-consuming materials for commercial green roof substrates is likely to be uneconomical. This study investigated the potential for use of waste materials including silica wastes as a byproduct of metallic ferrosilicon alloys as a component of the substrate for extensive green roofs. Particle size distribution, bulk density, mass, water capacity, soil reaction, and total dissolved salt content of Si-waste growing media were compatible with FLL standards. However, of greater importance for the structure of substrates was the effect of the Si wastes on the fertility of growing media. Engineered substrates had higher amounts of $\mathrm{P}, \mathrm{K}, \mathrm{Mg}, \mathrm{S}$, and other nutrients than the control media. Our results suggest that alkaline (well drained and containing immobile forms of organic matter Si-waste substrates) reduce the availability of potentially toxic metals to the root system, preventing its phytotoxicity for plants. They have the potential to maintain $\mathrm{pH}$ with high buffering capacity. Si wastes had a positive impact on plant growth and biomass. We consider that Si wastes may be a valuable and environmentally responsible green roof media amendment.

\section{Acknowledgements}

This research was financed by the Ministry of Science and Higher Education of the Republic of Poland.

\section{References}

1. OBERNDORFER E., LUNDHOLM J.,BASS B., COFFMAN R., DOSHI H., DUNNETT N., GAFFIN S., KOHLER M., LIU K.K.Y., ROWE B. Green roofs as urban ecosystems: ecological structures, functions and services. BioScience 57, 823, 825, 2007.

2. CARSON T., HAKIMDAVAR R., SJOBLOM K., CULLIGAN, P. Viability of recycled and waste materials as green roof substrates. Geo Congress 3644, 2012.

3. FASSMAN-BECK E.A., SIMCOCK R. Living roof review and design recommendations for stormwater management. Prepared by Auckland UniServices for Auckland Council. Auckland Council technical report TR2013/045. 2013.

4. AMPIN P.A.Y., SLOAN J.J., CABRERA R.I., HARP D.A., JABER F.H. Green roof growing substrates: types, ingredients, composition and properties. J. Environ. Hort. 28 (4), 244, 2010.

5. MOLINEUX C., FENTIMAN C., GANGEA. Characterizing alternative recycled waste materials for use as green roof growing media in the U.K. Ecol Eng 35, 1507, 2009.

6. OLSZEWSKI M.W., YOUNG C.A. Physical and chemical properties of green roof media and their effect on plant establishment. J.Environ. Hort. 29 (2), 81, 2011.

7. YOUNG T., CAMERON D.D., SORRILL J., EDWARDS T. Importance of different components of green roof substrate on plant growth and physiological performance. Urban For. Urban Green. 13, 507, 2014.

8. SUTTON K. Introduction to green goof ecosystems. Green Roof Ecosystems. Ecological Studies 223. Springer International Publishing Switzerland. 9, 115, 117, 148, 2015.

9. EMILSSON T. Vegetation development on extensive vegetated green roofs: influence of substrate composition, establishment method and species mix. Ecol. Eng. 33, 265, 2008.

10. BRADLEY D.B., MONTERUSSO M.A., RUGH C.L. Assessment of heat-expanded slate and fertility requirements in green roof substrates. HortTechnology, 16 (3), 471, 2006. 
11. FLL. Guidelines for the planning, execution and upkeep of green-roof sites. Forschungsgesellschaft Landschaftsentwicklung Landschaftsbau, Bonn. 2008.

12. SOLANO L., RISTVEY A.G., LEA-COX J.D., COHAN S.M. Sequestering zinc from recycled crumb rubber in extensive green roof media. Ecol. Eng. 47, 284, 2012.

13. BERTHELSEN S., NOBLE A.D., KINGSTON G., HURNEY A., RUDD A., GARSIDE A. Improving yield and ccs in sugarcane through the application of silicon based amendments. Final report SRDC Project CLW009. Sugar Research Australia Ltd. http://elibrary.sugarresearch.com. au, 2003.

14. PEREIRA H.S., GASPAR HENRIQUE KORNDÖRFER G.H., DE AQUINO VIDAL A., SARTORI DE CAMARGO M. Silicon sources for rice crop. Sci. Agric., 61 (5), 522, 2004.

15. GUNTZER F., KELLER C, MEUNIER J.P. Benefits of plant silicon for crops: a review. Agronomy for Sustainable Development, Springer Verlag/EDP Sciences/INRA, 32 (1), 201, 2012.

16. EPSTEIN E. Silicon. Annl. Rev. Plant Physiol. Plant Mol. Biol., 50, 641, 1999.

17. CROOKS R., PRENTICE P. The benefits of silicon fertiliser for sustainably increasing crop productivity. The 5th International Conference on Silicon in Agriculture: Silicon management for high crop productivity and quality and environmental health. Beijing, China. 2011.

18. DHIR R.K., NEWLANDS M.D., DYER T.D. Sustainable waste management. Proceedings of the International Symposium University of Dundee, 9-11 September 2003, Scotland, UK. 2003.

19. KOMORNICKI T. (ed.). Exercise guide book of soil science and geology for AR students. Department of Graphic PK in Krakow, Poland, 60-63. 1979 [In Polish].

20. OSTROWSKA A., GAWLIŃSKI S., SZCZUBIAŁKA Z. Soil and Plant Analysis Procedures. Wyd. Instytutu Ochrony Środowiska, Warsaw, 1991 [In Polish].

21. ONDOÑO S., MARTÍNEZ-SÁNCHEZ J.J., MORENO J.L. The inorganic component of green roof substrates impacts the growth of Mediterranean plant species as well as the $\mathrm{C}$ and $\mathrm{N}$ sequestration potential. Ecol. Indicators DOI: 10.1016/j.ecolind.2015.10.025, 2015.

22. THURING C.E., DUNNETT N. Vegetation composition of old extensive green roofs (from 1980s Germany). Ecol. Processes. 3, 4, 2014.

23. SCHRADER S., BÖNING M. Soil formation on green roofs and its contribution to urban biodiversity with emphasis on Collembolans. Pedobiologia 50, 347, 2006.

24. KÖHLER M., POLL P.H. Long-term performance of selected old Berlin green roofs in comparison to younger extensive green roofs in Berlin. Ecol Eng, 36, 722, 2010.

25. HINSINGER P. Plant-induced changes in soil processes and properties. (in:) Gregory P.J, Nortcliff S. (eds) Soil conditions and plant growth. Wiley-Blackwell, Chichester. 2013.

26. KABATA-PENDIAS A. Trace elements in soils and plants. Taylor and Francis, Londyn. 2011.

27. FURINI A. Plants and heavy metals. SpingerBrief in Molecular Science. Biometals. Springer, the Netherlands. 2012.

28. TURNAU K., ANIELSKA T., RYSZKA P., GAWROŃSKI S., OSTACHOWICZ B., JURKIEWICZ A. Establishment of arbuscular mycorrhizal plants originating from xerothermic grasslands on heavy metal rich industrial wastes - new solution for waste revegetation. Plant. Soil. 305, 267, 2008.

29. BARKER A.V., PILBEAM J.D. Handbook of plant nutrition. Taylor \& Francis Group, Boca Raton, 28, 2007.

30. TURNAU K., OSTACHOWICZ B., WOJTCZAK G., ANIELSKA T., SOBCZYK Ł. Metal uptake by xerothermic plants introduced into $\mathrm{Zn}-\mathrm{Pb}$ industrial wastes. Plant. Soil. 337, 299, 2010.

31. ADREES M., ALI S., RIZWAN M., ZIA-UR-REHMAN M., IBRAHIM M., ABBAS F., FARID M., QAYYUM M.F., IRSHAD M.K. Mechanisms of silicon-mediated alleviation of heavy metal toxicity in plants: A review. Ecotoxicol. Environ. Saf. 119, 186, 2015.

32. MENGEL K., KIRKBY E.A. Principles of plant nutrition, $5^{\text {th }}$ edt. Kluwer, Dordrecht. 2001. 